\title{
A SURVEY OF THE ALGAL FLORA OF ANTHROPOGENIC CAVES OF CAMPI FLEGREI (NAPLES, ITALY) ARCHEOLOGICAL DISTRICT
}

\author{
Paola Cennamo ${ }^{*}$, Chiara Marzano ${ }^{2}$, Claudia Ciniglia ${ }^{3}$, Gabriele Pinto ${ }^{2}$, Piergiulio Cappelletti ${ }^{4}$, \\ Paolo Caputo ${ }^{2}$, and Antonino Pollio 2
}

\begin{abstract}
Campi Flegrei is a large volcanic area situated northwest of Naples, Italy. Two archeological sites, the Sybil's Cave and the Piscina Mirabilis, are artificial caves dug in the yellow tuff and used during antiquity for various purposes. This paper describes for the first time the algal biodiversity of these caves and determines whether environmental factors such as light intensity and humidity are influential in species distribution. A total of twenty-two algal species were identified by molecular methods (18S rDNA); the largest group was Cyanobacteria (eleven species), followed by algae Chlorophyta (six), Rhodophyta (two) and Bacillariophyta (two). Cluster analysis of algal distribution in the caves in relation to light and humidity showed no relevant differences in algal distribution between the two caves. Three different algal groups were identified. The first one includes strains strictly dependent on low humidity, a second cluster was mainly associated with sites where humidity is not a severe constraint, and a third group, mainly represented by filamentous cyanobacteria, is probably dependent on high humidity, since it was detected only at Piscina Mirabilis.
\end{abstract}

\section{INTRODUCTION}

The algal flora of caves is drawing increasing attention due to the peculiarities of their environment. Reduced light intensity, low nutrient input, and absence of seasonality (Dayner and Johansen, 1991; Pedersen, 2000) are the predominant features that influence distribution and composition of algal assemblages in natural and artificial caves, but temperature, humidity, and occurrence of flowing water also play a role in the establishment of algal settlements (Mulec et al., 2007). Many cave habitats currently suffer the impact of increasing tourist fluxes; artificial lights and human traffic are strong factors that can deeply modify equilibria within algal populations (Chelius et al., 2009). An example is given by the anthropogenic caves occurring in the archaeological district of Campi Flegrei in Italy, an area that is the single largest feature of the Phlegraean Volcanic District, which includes the islands of Procida and Ischia, as well as submarine vents in the northwestern bay of Naples (Orsi et al., 1996). Campi Flegrei has been inhabited since prehistoric times and became an important center of civilization during antiquity. Different underground habitats have been dug in the district, and two of them have remarkable dimensions. The most ancient is the so-called Sybil's Cave (fourth century BCE), near Cuma, which is in fact a long gallery cut into the soft tuff, lighted by multiple openings to the surface. The other large cave (dating back to the first century CE) is the Piscina Mirabilis, located in Baia, a cistern also excavated in tuff, used to store drinking water. The two caves present some common features. They share the same external climatic conditions, being located less than 6 kilometers from each other, and similar viable algal propagules can be dispersed into both caves by air currents and transport by animals (Dobat, 1970). In addition, they have been dug in the same geological material that originated from the eruption of the Neapolitan Yellow Tuff (dated at $15 \mathrm{ka}$ BP; Insinga et al., 2004), which produced the caldera collapse of the bay of Pozzuoli (Scarpati et al., 1993).

On the other hand, the two caves differ in some characteristics. The Sybil's Cave is, in part, directly lightened by daylight and is visited by numerous tourists throughout the year, whereas the Piscina Mirabilis does not receive direct light and is rarely open to the public. Moreover, it has been partially filled for centuries with freshwater with a high carbonate concentration, causing the formation of calcareous incrustations along the walls of the cave, and groundwater infiltrations are still frequent. The Sybil's Cave is a dry habitat, with very little water infiltration. The similarities and differences present an opportunity for observing how they influence the composition of the algal assemblages in the two caves and could help to clarify the contribution of microalgae to deterioration processes.

Biodeterioration in caves occurs as a consequence of the presence of microbial communities, formed of algae, bacteria, and fungi, that develop thick biofilms on any rock surface, leading to decay (Albertano et al., 2003). Subterranean algal communities are generally divided into

\footnotetext{
*Corresponding author: pcennamo@unina.it

${ }^{1}$ Facoltà di Lettere, Università degli Studi 'Suor Orsola Benincasa', Via S. Caterina da Siena 37, I-80135 Napoli, Italy

${ }^{2}$ Dipartimento delle Scienze Biologiche, Università degli Studi di Napoli 'Federico II', Orto Botanico, Via Foria 223, Napoli I-80139, Italy

${ }^{3}$ Dipartimento di Scienze della Vita, Seconda Università di Napoli, Via Vivaldi 43, Caserta I- 81100, Italy

${ }^{4}$ Dipartimento di Scienze della Terra, Università degli Studi di Napoli 'Federico II', Via Mezzocannone 8, Napoli I-80134, Italy
} 


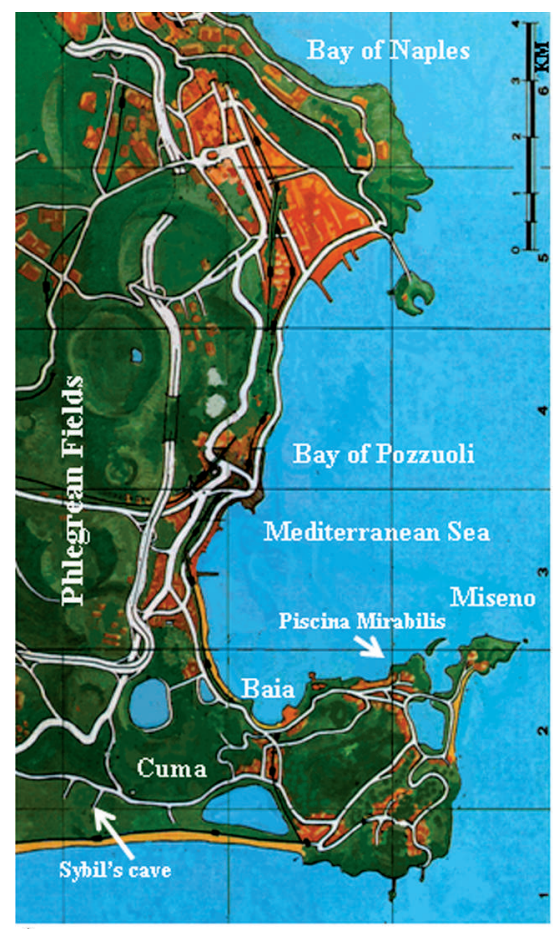

A

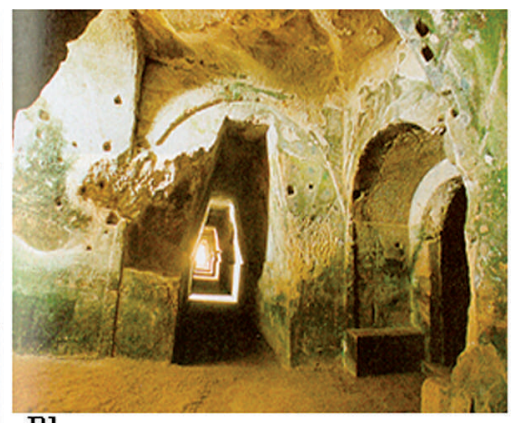

Bl

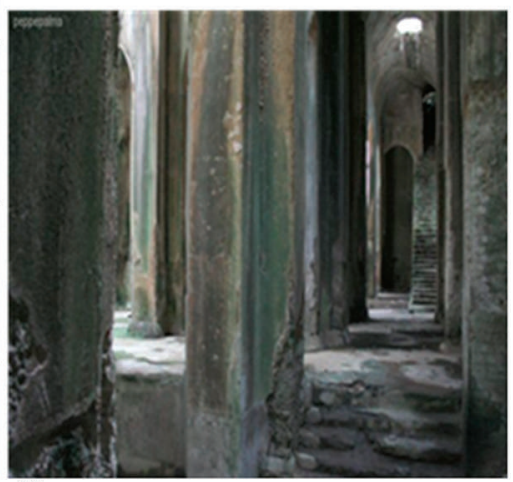

$\mathrm{Cl}$

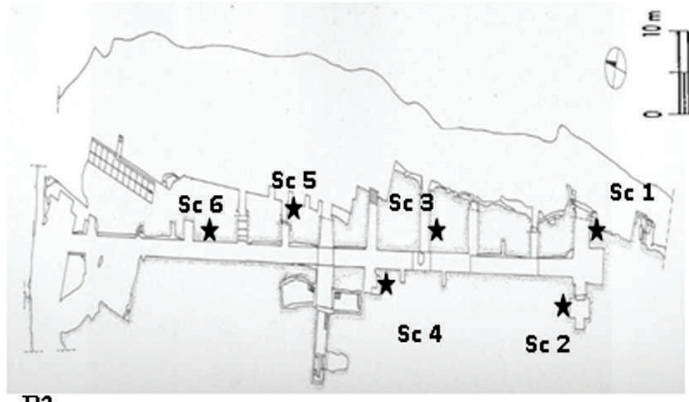

B2

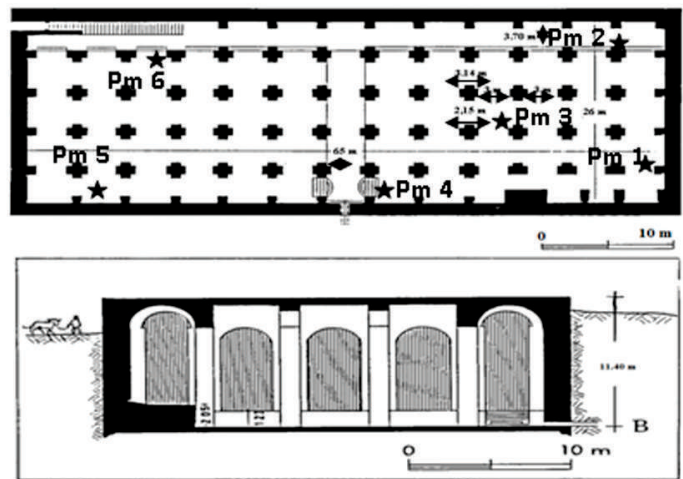

$\mathrm{C} 2$

Figure 1. A, map of Phlegrean Fields. B1, picture of the Sybil's Cave. B2, map of and locations of the sampling sites in the Sybil's Cave (Pagano et al., 1982). C1, picture of the Piscina Mirabilis. C2, map of and locations of the sampling sites in the Piscina Mirabilis (Rajola et al., 1978).

the so-called lampenflora, formed by specialized organisms that thrive only in underground habitats in the presence of artificial light, and areophilic flora, composed by terrestrial microalgae, mainly belonging to Chlorophyta and diatoms that tolerate cave environmental conditions, especially at the openings of caves (Mulec et al., 2008). Cyanobacteria are the key organisms in the genesis of biofilms, being able to produce exopolymeric substances that allow the formation of the microbial community and its adhesion to rocks (Stal, 2000). Cyanobacteria exposed to high light intensities may have an endolithic phase of growth, changing the mineral structure of the rock and determining its decay (Asencio and Aboal, 2001).

In an attempt to ascertain the potential damage caused by the algal flora on the underground monuments of Campi Flegrei, a systematic survey of the algal flora from the two anthropogenic caves has been attempted. At the same time, considering that the algae living in these habitats cannot be considered solely as a threat, but also as an important source of biodiversity, an effort was undertaken to isolate and maintain the strains in the algal collection of University Federico II of Naples to study their ecophysiological features.

\section{EXPERIMENTAL METHODS}

The Sybil's Cave, built in the fourth century BCE, is a trapezoidal passage over $131 \mathrm{~m}$ long running parallel to the side of the hill on which was built the Acropolis of Cuma at
Campi Flegrei (Fig. 1 B1, B2). It was cut out in the volcaniclastic Neapolitan Yellow Tuff. The gallery leads to a more enclosed polygonal hall; the main entrance and the openings along the hallway ensure the entrance of light and a continuous flux of air.

The Piscina Mirabilis, built in the first century CE, is a cistern dug in the tuff, $70 \mathrm{~m}$ long, $25.50 \mathrm{~m}$ wide, and $15 \mathrm{~m}$ deep (Fig. $1 \mathrm{C} 1, \mathrm{C} 2$ ). The cavity has a rectangular layout with forty-eight tuff pillars covered in opus reticulatum, a form of brickwork used in ancient Roman architecture consisting of diamond-shaped bricks of tuff placed around a core of concrete, and is divided into four corridors that compose the inner part of the cistern. The outer walls, in opus reticulatum, are covered with a thick layer of cocciopesto, mortar with potsherds. The Piscina Mirabilis supplied drinking water for the Roman fleet that was based in Misenum, near Baiae (Fig. 1 A).

Due to their orientation and position, the entrances of both caves are directly illuminated throughout the year. Moreover, the openings present in the Sybil's Cave allow penetration of light during the whole day, whereas the Piscina Mirabilis is always shady. Six sampling points were selected in each cave, on the basis of light, temperature, and relative humidity data (Fig. 1 B2, C2). They showed evidence of biodeterioration in the form of a green and brown patina. Ten samplings were carried out within a $20 \times 20 \mathrm{~cm}$ square at each point.

Biofilm samples were collected in the autumn of 2009 by scraping the walls of the caves with a sterile scalpel and 
Table 1. Temperature, light intensity and relative humidity of the Sybil's Cave (SC) and the Piscina Mirabilis (PM) sample sites.

\begin{tabular}{lccc}
\hline Sample Sites & $\begin{array}{c}\text { Temperature, } \\
{ }^{\circ} \mathrm{C}\end{array}$ & $\mu \mathrm{E}, \mathrm{m}^{-2} \mathrm{~s}^{-1}$ & $\begin{array}{c}\text { Relative } \\
\text { Humidity, \% }\end{array}$ \\
\hline SC1 & $17 \pm 2$ & $0.05 \pm 0.002$ & $69 \pm 1$ \\
SC2 & $18 \pm 2$ & $0.02 \pm 0.001$ & $69 \pm 1$ \\
SC3 & $18 \pm 2$ & $0.16 \pm 0.007$ & $69 \pm 2$ \\
SC4 & $19 \pm 2$ & $0.4 \pm 0.02$ & $68 \pm 2$ \\
SC5 & $19 \pm 2$ & $0.407 \pm 0.02$ & $69 \pm 2$ \\
SC6 & $19 \pm 2$ & $3.31 \pm 0.15$ & $72 \pm 3$ \\
PM1 & $16 \pm 1$ & $0.15 \pm 0.006$ & $85 \pm 1$ \\
PM2 & $16 \pm 1$ & $0.15 \pm 0.006$ & $86 \pm 1$ \\
PM3 & $16 \pm 1$ & $0.22 \pm 0.01$ & $84 \pm 1$ \\
PM4 & $16 \pm 1$ & $0.46 \pm 0.02$ & $81 \pm 1$ \\
PM5 & $16 \pm 1$ & $0.05 \pm 0.002$ & $80 \pm 2$ \\
PM6 & $16 \pm 1$ & $2.61 \pm 0.13$ & $75 \pm 2$ \\
\hline
\end{tabular}

depositing materials into sterile vials containing either a specific medium for Cyanobacteria (BG11; Castenholz, 1988) or BBM (Bold Basal Medium; Bischoff and Bold, 1963) for all other microalgae. Samples were collected in September, October, and November (Table 1). Temperature, light intensity, and relative humidity were measured at each sampling site by using appropriate instruments (TESTO 174, TESTO 545, AG Germany). Light irradiance at each sampling point was measured by using a LI-COR radiation sensor (BIOSCIENCES).

The algal samples were inspected using an optical microscope (Nikon Eclipse E800 equipped with Nomarski interference, magnification $\times 100$ ). Small fragments of biofilms, after critical-point drying, were gold-coated in an Emitech k550 Sputter Coater and observed by scanning electron microscopy (Philips EM 208S).

Quantitative mineralogical analysis and the chemical composition of rocks collected in the sampling areas were determined by means of x-ray powder diffraction and environmental scanning electron microscope. The $\mathrm{x}$-ray diffraction was performed with a Panalytical X'Pert Pro modular diffractometer, and quantitative analyses were obtained by the Rietveld method (Bish and Post, 1993). Chemical elements were measured using a microanalysis system (ZAFPB).

Quantitative estimations of the identified taxa were also made. For algal counts, $0.5 \mathrm{~g}$ of fresh biofilm sample was suspended and fixed in $100 \mathrm{~mL}$ of aqueous solution of formaldehyde $(3 \%)$ and counted with a hemocytometer within 24 hours. To establish species compositions, part of each suspension was put on a slide, and twenty randomly chosen microscope fields were counted using a grid (LUCIA version 4.60 System for Image Processing and Analysis); at least one hundred cells were counted per slide. Three such slides were counted for each sample, and the means were analyzed for significant variance (Student's t-test). The relative standard error was never higher than 5\%. The count of filamentous Cyanobacteria was carried out by counting filaments in transects of a chamber filled with a few milliliters for sedimentation over night. Backcalculating to a ml of sample was carried out by considering the volume of the counting chamber and measuring the area of the transects and of the chamber bottom (Lawton et al., 1999).

Additionally, the identification of the microbial components of biofilms was accomplished by molecular techniques. DNA was extracted using a procedure described by Doyle and Doyle 1990. PCR amplification was carried out on an estimated $10 \mathrm{ng}$ of extracted DNA. For Cyanobacteria, the primer set for $16 \mathrm{~S}$ rDNA (Díez et al., 2001) was used; for algae, the primer set for $18 \mathrm{~S}$ rDNA indicated by Huss et al. (1999) was used. PCR reactions were carried out in a final volume of $50 \mu \mathrm{L}$ containing $5 \mu \mathrm{L}$ of $10 \times$ PCR buffer, $100 \mathrm{mM}$ of deoxynucleotide triphosphate, $2.5 \mathrm{mM}$ of magnesium chloride, $0.5 \mathrm{mM}$ of primers, and $1 \mathrm{U}$ of Taq polymerase (Quiagen, Hilden, Germany). The PCR program consisted of an initial denaturation at $95{ }^{\circ} \mathrm{C}$ for $4 \mathrm{~min}$ and 30 cycles including $1 \mathrm{~min}$ of denaturation at $94{ }^{\circ} \mathrm{C}, 45 \mathrm{~s}$ of annealing at $56^{\circ} \mathrm{C}$, and 2 min extension at $72{ }^{\circ} \mathrm{C}$. A final extension of $7 \mathrm{~min}$ at $72{ }^{\circ} \mathrm{C}$ followed by cooling at $4{ }^{\circ} \mathrm{C}$ terminated the PCR program.

The identification of the entire community was obtained employing cloning libraries. An aliquot of purified PCR product was ligated into the pGEM-T easy Vector system (Promega, Vienna, Austria), and clones were screened and sequenced with a 3130 genetic analyzer (Applied Biosystems). The sequences obtained were compared with available sequences in the GeneBank database. Cluster analysis to detect possible grouping of algal taxa in terms of environmental preferences was carried out by using the SYNTAX vers. 5.1 computer program for data analysis in ecology and systematics (Podani, 2001).

\section{RESUlts AND Discussion}

At all the sampling points, mean midday temperature was $18 \pm 2{ }^{\circ} \mathrm{C}$ in the Sybil's Cave (SC) and $16 \pm 1{ }^{\circ} \mathrm{C}$ in the Piscina Mirabilis (PM). The mean amount of photosynthetically active radiation in SC ranged from 0.0165 to $3.31 \mu \mathrm{E} \mathrm{s}^{-1} \mathrm{~m}^{-2}$, whereas in PM values at sampling points 1 to 6 ranged from 0.049 to $2.61 \mu \mathrm{E} \mathrm{s}^{-1} \mathrm{~m}^{-2}$ (Table 1). Relative humidity in SC ranged from 69 to $72 \%$; on the other hand, the relative humidity of PM was in the range 75 to $86 \%$ (Table 1 ).

Light microscopy revealed the presence of taxa belonging to Cyanobacteria, Chlorophyta, Bacillariophyta, and Rhodophyta. The variations in relative abundance of these taxa among the various sampling point in the two caves are shown in Figure 2. Cyanophyta were the dominant taxa at several sampling points, both in SC (sites 1 to 4 ) and in PM (sites 1 to 4), where Cyanobacteria cell percentages ranged from 50 to $80 \%$ in SC and from 70 to $85 \%$ in PM. At the same sites, Chlorophyta represented a minor percentage

Journal of Cave and Karst Studies, December 2012 •245 

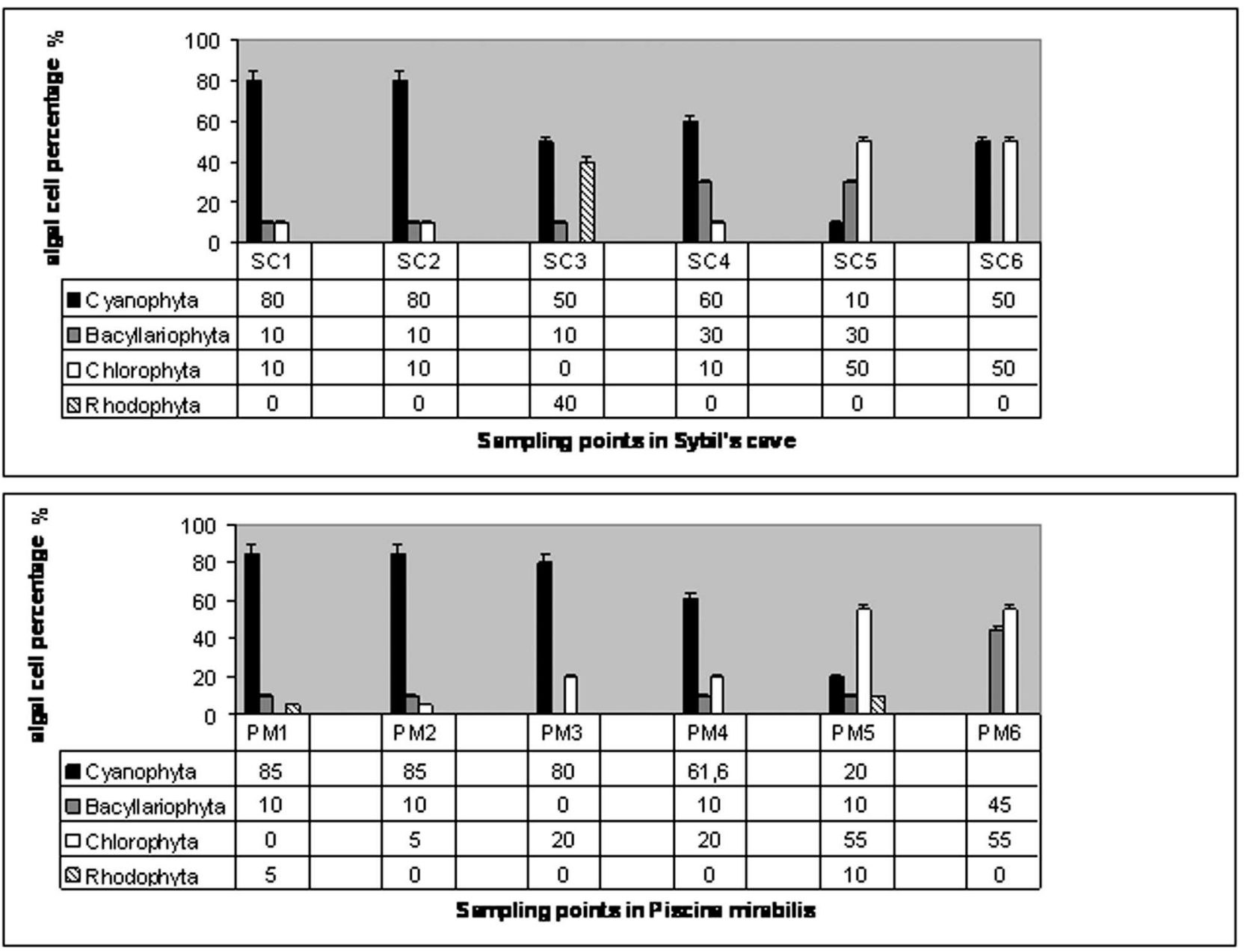

Figure 2. Microbial composition of biofilms in the Sybil's Cave and the Piscina Mirabilis.

(less than $25 \%$ ) of the algal population, but at SC5, PM5, and PM6, where cyanophytes were scarcely represented, chlorophytes prevailed, with their relative abundance being directly proportional to the increase in light intensity. Bacillariophyta (diatoms) normally did not exceed $10 \%$ in $\mathrm{SC}$ and in PM; at SC4, SC5, and PM6, however, they were 30 and $45 \%$ respectively. Rhodophyta were abundant only at $\mathrm{SC} 3$, at relatively low light intensity, while in PM their percentages never exceeded $10 \%$.

Microanalyses of the substrate, always composed of Neapolitan Yellow Tuff (NYT), revealed the presence of the same elemental composition in both sites ( $\mathrm{Al}, \mathrm{Ba}, \mathrm{Cd}$, $\mathrm{Co}, \mathrm{Cu}, \mathrm{Fe}, \mathrm{K}, \mathrm{Mg}, \mathrm{Mn}, \mathrm{Na}, \mathrm{Si}, \mathrm{Sr}, \mathrm{Ti}, \mathrm{U}$, and $\mathrm{Zn}$ ), albeit elements were present at different concentrations. Mineralogical composition of investigated samples confirmed the composition of NYT, mainly phillipsite, chabazite, and analcime, and hydrous aluminosilicates pertaining to the zeolite group, along with feldspars and minor amounts of clay minerals (de'Gennaro et al., 2000). Data from the literature (Morra et al., 2010) state high porosity values for NYT, which is characterized, moreover, by the presence of micropores causing a high capillary absorption of water that allows microbial growth. SEM observations showed that the microbial community is embedded in an exopolysaccharidic matrix that facilitates the establishment of strong bonds between biofilm and substrate (Fig. 3). In both sites, Cyanobacteria adhered strictly to NYT, offering an ideal environment for the growth of other organisms, giving endurance and thickness to the biofilm.

Identification of many algal strains is difficult because of the scarcity of useful features and the homoplasious morphology of some lineages. To minimize the risk of erroneous identifications, molecular techniques were also used. Only the most similar sequence matches ( $90 \%$ identity) with GenBank have been considered. Sequencing revealed a total of seventeen phylotypes for SC and thirteen for PM that were assigned to Cyanophyta (eleven taxa), Rhodophyta (two taxa), Chlorophyta (six taxa) and Bacillariophyta (two taxa) (Table 2).

A hierarchical clustering was carried out on a dissimilarity matrix based on the presence/absence of algal taxa in different sampling sites at different light intensities and relative humidities (Jaccard coefficient $1-a /(a+b+c)$ ). Two classes of humidity were defined for the analysis, low humidity (less than 


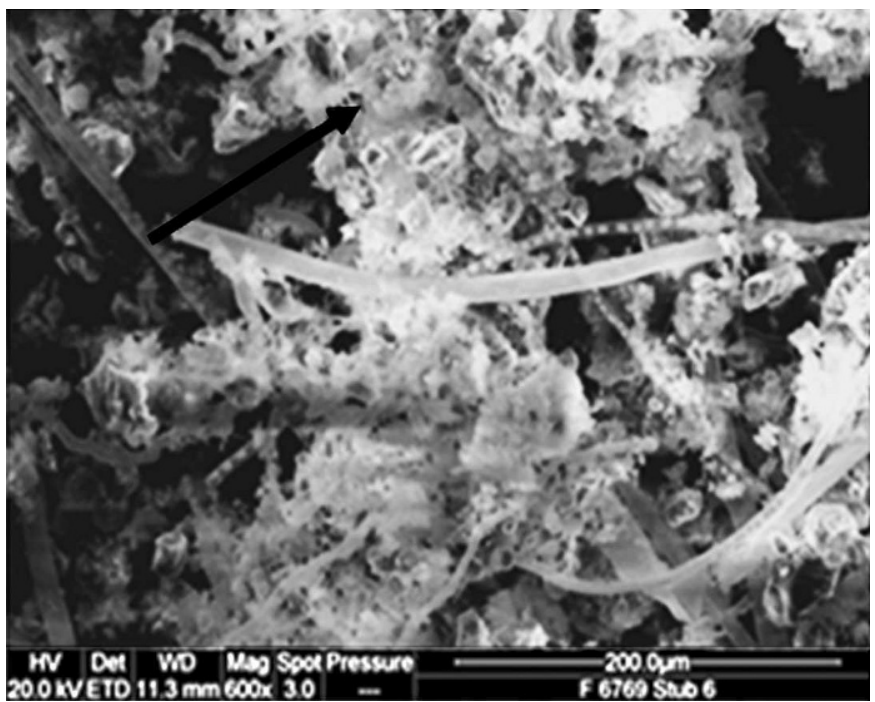

Figure 3. Scanning electron micrograph (SEM) showing microbial community embedded in an esopolysaccharidic matrix (arrow).

$75 \%$ ) and high humidity ( 77 to $82 \%$ ), as well as three classes of light intensities, low intensity (from 0.017 to $0.198 \mu \mathrm{E} \mathrm{s}^{-1} \mathrm{~m}^{-2}$ ), intermediate intensity (from 0.33 to $0.4125 \mu \mathrm{E} \mathrm{s}^{-1} \mathrm{~m}^{-2}$ ), and high intensity (above $2.607 \mu \mathrm{E} \mathrm{s}^{-1} \mathrm{~m}^{-2}$ ). As shown in Figure 4, algal strains are grouped in two distinct clusters: group A (eight strains), which includes strains found only at low humidity; Aphanotecae sp., Chroococcus lithophilus, Gloeocapsa sp., Gloeocystis sp., and Scenedesmus arcuatus sp. are grouped in the same subgroup, since they have been found in sampling sites with both medium and high light intensities. Pseudococcomya simplex and Cyanobium bacillare appear distantly related to this subgroup, as these taxa colonize low intensity sites and high intensity sites, respectively. A second cluster (group B) includes two subgroups. In subgroup B1, all species are not affected by humidity; Chroococcus varius, Navicula sp., Chlorella sp., Stichococcus sp. and Scotiellopsis terrestis are ubiquitous strains, while Oscillatoria sp., Synechococcus sp., Cyanidium sp., and Phragnonema sordidum have been detected only in sampling sites with low to medium light intensities. A third group representing Subgroup B2 includes Leptolyngbya fragilis, L. foveolarum, Lyngbya sp., and Nostoc commune; these strains were detected only in PM, thus suggesting that they are probably dependent on high humidity.

The Sybil's Cave and the Piscina Mirabilis share some important physico-chemical characters: location, anthropogenic origin, Mediterranean climate, and nature of the substrate. Microbial colonization of rock substrates is highly dependent on their features (Macedo et al., 2009), and in the case of SC and PM, surface roughness, porosity, and mineral composition of the rock promote in the same way the establishment of microbial assemblages. Temperature, irradiation, and relative humidity are relevant differences between SC and PM. In the inner part of the former, light intensity is very reduced $\left(<0.01 \mu \mathrm{E} \mathrm{s}^{-1} \mathrm{~m}^{-2}\right)$, but temperature and relative humidity are comparable to open-air values. Similar values of relative humidity were reported by Hoffman (1989) for another anthropogenic cave, the Roman necropolis in Seville, Spain. SC cannot be considered a typical cave environment, but rather a poorly illuminated aerial habitat, where temperature and relative humidity are heavily influenced by the external climatic conditions due to the presence of large opening in the rock walls of the cave. On the other hand, PM is a dim environment with a mild temperature and a relative humidity comparable to that recorded from numerous natural caves, whose values range from 76 to 96\% (Couté and Yéprémian, 2002).

In the dark area of SC, Cyanophytes are the dominant organisms, being represented by Synechococcus sp. and Cyanobium bacillare and Oscillatoria sp. Oscillatoria has been frequently encountered in European caves (Couté and Yéprémian, 2002). It is a pioneer organism because of its capacity to grow diazotrophically (Gallon et al., 1991). Moreover, as other members of Oscillatoriales, it is well adapted to extremely low irradiance compared to other filamentous Cyanophyta (Albertano et al., 2000). The presence of Synechococcus and of the closely related Cyanobium bacillare in sampling points 1 and 2 of SC confirms that the average temperature of SC during the year is not particularly low, since this species does not thrive in cold environments (Sakamoto and Bryant, 1999). Synechococcus is not a typical cave organism: its occurrence has been reported on both marble and granite monuments in different Mediterranean countries (Crispim and Gaylarde, 2005), and it also can grow endolithically (Saiz-Jimenez et al., 1990). Chroococcus lithophilus and $C$. various, together with Gloeocapsa sp., are the dominant Cyanobacteria in the whole Sybil Cave, where light intensity is greater than $0.01 \mu \mathrm{E} \mathrm{s}^{-1} \mathrm{~m}^{-2}$. The increase in Chroococcacean species at low levels of irradiation seems to be a standard feature of cave algal assemblages (Asencio and Aboal, 2001), even though the occurrence of Chroococcus and Gloeocapsa has been reported not only in dim habitats, but also on monuments exposed to daylight (Scheerer et al., 2009), confirming the tolerance of these organisms to a wide range of environmental conditions.

The algal communities of PM can be split in two types: the first, found in points 1 through 3 , is mainly composed by filamentous Cyanobacteria. Nostoc commune is the dominant species, responsible for the formation of thick mats containing also Leptolynbya fragilis, L. foveolarum, and Lyngbya sp. filaments, along with Chroococcacean species as Synechococcus sp. and Cyanobium bacillare. The dominant presence of filamentous cyanobacteria in stable conditions of low light intensity and high relative humidity has been reported for different caves (Martinez and Asencio, 2010; Roldàn and Hernández-Mariné, 2009). Nostoc is a cosmopolitan terrestrial genus that can endure desiccation, as well as very low temperatures (Dodds et al., 1995). However, the persistence of Nostoc commune seems to be determined 
Table 2. List of algal taxa at sampling sites in the Sybil's Cave (SC) and in the Piscina Mirabilis (PM).

Sampling Sites

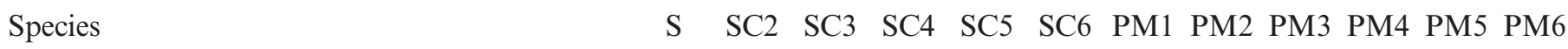

\section{PROKARYOTA}

\section{CYANOPHYTA}

Aphanotecae sp.

Chroococcus lithophilus Ercegović

Chroococcus varius A. Braun in Rabehorst

Gloeocapsa sp.

Leptolyngbya foveolarum (Rabenhorst ex

Gomont) Anagnostidis et komárek

Leptolyngbya fragilis (Gomont)

Anagnostidis et komárek

Lyngbya sp.

Nostoc commune Vaucher ex Bornet \&

Flahault

Oscillatoria sp.

Synechococcus sp.

Synechococcus bacillaris Cyanobium

bacillare (Butcher) J. Komárek,

J. Kopeck \& V. CepàK

\section{EUKARYOTA}

\section{BACILLARIOPHYTA}

Navicula sp.

Pinnularia obscura Krasske

\section{CHLOROPHYTA}

Chlorella sp. Beijerinck

Gloeocystis sp.

Stichococcus sp.

Scenedesmus arcuatus Lemmrmanm

Scotiellopsis terrestris (H. Reislig)

Pucocharova \& Kalina

Pseudococcomya simplex (Mainx) Fott

\section{RHODOPHYTA}

Cyanidium sp.

Phragnonema sordidum Zopf

$$
\begin{array}{llllllllllll}
\cdots & \cdots & \cdots & \mathrm{X} & \mathrm{X} & \mathrm{X} & \cdots & \cdots & \cdots & \cdots & \cdots & \cdots \\
\cdots & \cdots & \mathrm{X} & \mathrm{X} & \mathrm{X} & \mathrm{X} & \cdots & \cdots & \cdots & \cdots & \cdots & \cdots \\
\cdots & \cdots & \mathrm{X} & \mathrm{X} & \mathrm{X} & \mathrm{X} & \cdots & \cdots & \cdots & \mathrm{X} & \mathrm{X} & \mathrm{X} \\
\cdots & \cdots & \mathrm{X} & \mathrm{X} & \mathrm{X} & \mathrm{X} & \cdots & \cdots & \cdots & \cdots & \cdots & \cdots \\
\cdots & \cdots & \cdots & \cdots & \cdots & \cdots & \mathrm{X} & \mathrm{X} & \cdots & \cdots & \cdots & \cdots \\
& & & & & & & & & & & \\
\cdots & \cdots & \cdots & \cdots & \cdots & \cdots & \mathrm{X} & \mathrm{X} & \cdots & \cdots & \cdots & \cdots \\
& & & & & & & & & & & \\
\cdots & \cdots & \cdots & \cdots & \cdots & \cdots & \mathrm{X} & \mathrm{X} & \cdots & \mathrm{X} & \cdots & \cdots \\
\cdots & \cdots & \cdots & \cdots & \cdots & \cdots & \cdots & \cdots & \mathrm{X} & \cdots & \cdots & \cdots \\
& & & & & & & & & & & \\
\mathrm{X} & \mathrm{X} & \cdots & \cdots & \cdots & \cdots & \mathrm{X} & \cdots & \mathrm{X} & \cdots & \cdots & \cdots \\
\mathrm{X} & \mathrm{X} & \cdots & \cdots & \cdots & \cdots & \mathrm{X} & \mathrm{X} & \mathrm{X} & \cdots & \cdots & \cdots \\
\mathrm{X} & \mathrm{X} & \cdots & \cdots & \cdots & \cdots & \cdots & \cdots & \cdots & \cdots & \cdots & \cdots
\end{array}
$$

by the occurrence of liquid water (Stal, 2000). This feature could account for the sharp difference observed in community composition between the Sybil's Cave and the Piscina Mirabilis; in the first, a dry habitat, Nostoc commune was not recovered at any light intensity, whereas in PM, an intense growth of this Cyanophyta was observed where light intensity was low.

Chlorophyta and diatoms found in points 4 to 6 of both SC and PM are typical members of algal aerial communities. Chlorophyta genera such as Chlorella, Stichococcus, and Scotiellopsis and diatom genera such as Navicula, and Pinnularia are ubiquitous and well-adapted to colonize a wide range of substrata, regardless of microclimatic and environmental conditions (Macedo et al., 2009). Pinnularia obscura has been detected in thermoacidic environments of
Campi Flegrei (Ciniglia et al., 2007), and it is probably widely distributed in the whole district.

The cluster analysis of algal distribution in the Sybil's Cave and the Piscina Mirabilis as related to light and humidity showed that the most relevant differences in the algal distributions was the detection of filamentous Cyanobacteria exclusively in the Piscina Mirabilis. This group of organisms seems to prefer high and constant values of relative humidity together with low light intensities, which were not recorded in the Sybil's Cave.

Also noteworthy is the presence in both caves of two rare unicellular red algae, Cyanidium sp. and Phragnonema sordidum. The occurrence of $P$. sordidum in SC was reported for the first time by Sieminska (1962), who recovered the alga on a shady and damp wall of this 


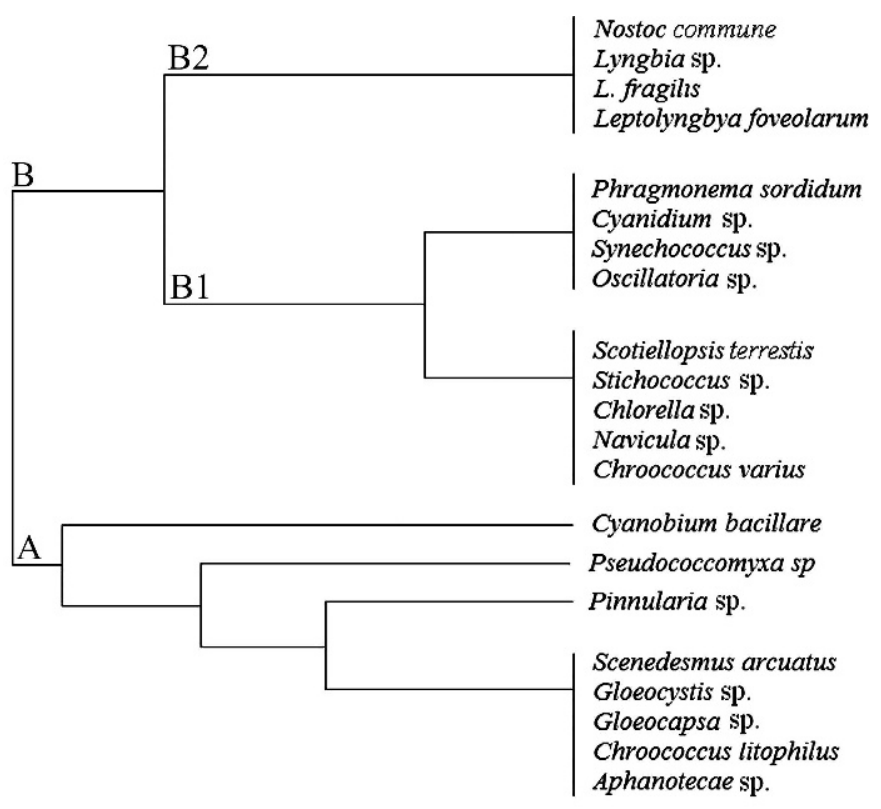

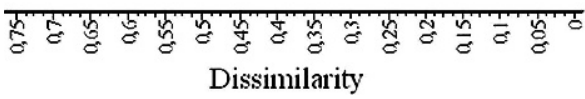

Figure 4. Hierarchical clustering of the algal strains based on light and humidity. The major clusters described in the text are, from the bottom up, A, B1, and B2.

cave. In $\mathrm{SC}, P$. sordidum is frequently associated with Synechococcus, and it occurs in all the stages of its life cycle. The presence of $P$. sordidum has been recorded in other caves in the Mediterranean region (Friedmann, 1956), as well as on monuments in the Deux Sèvres district, France, under low light intensity (Le Clerc et al., 1983) and in hypogaean Roman archeological sites (Albertano, 1993).

The genus Cyanidium encompasses unicellular algae recently placed in the phylum Cyanidiophyta (Saunders and Hommerstand, 2004) among the Rhodophyta. This genus includes both thermoacidophilic organisms, such as the well known $C$. caldarium, ubiquitously present in thermoacidic environments (Pinto et al., 2007), as well as mesophilic ones, as reported by Schwabe $(1936,1944)$ on the walls of Chilean coastal caves with no water seepage. According to Ott and Seckbach (1994), the mesophilic strain is clearly different from C. caldarium, on the basis of its mesophilic character and its habitat, but its geographic distribution is presently not known. Since the studies of Schwabe (1936, 1944), cave Cyanidium taxa have been found in many other sites, from the Negev Desert, Israel (Friedmann, 1956) to France and Italy (Hoffmann 1986, Skuja, 1970).

\section{Conclusions}

The Campi Flegrei district presents many other hypogean monuments that have not yet been explored for their algal communities. Studies are in progress to extend our knowledge of the algal biodiversity occurring in these peculiar habitats.

\section{REFERENCES}

Albertano, P., 1993, Epilithic algal communities in hypogean environments: Giornale Botanico Italiano, v. 127, no. 3, p. 386-392.

Albertano, P., Bruno, L., D’Ottavi, D., Moscone, D., and Palleschi, G., 2000 , Effect of photosynthesis on $\mathrm{pH}$ variation in cyanobacterial biofilms from Roman catacombs: Journal of Applied Phycology, v. 12, p. 279-384. doi:10.1023/A:1008149529914.

Albertano, P., 2003, CATS - Cyanobacteria attack rocks: control and preventive strategies for avoiding damage caused by cyanobacteria and associated micro-organisms in Roman hypogean monuments, in Kozlowski, R., et al., eds., Proceedings of the 5th EC Conference on Cultural Heritage Research: a Pan-European Challenge, Cracow, EUICSC, $394 \mathrm{p}$.

Albertano, P., Moscone, D., Palleschi, G., Hermosin, B., Saiz-Jimenez, C., Sanchez-Moral, S., Hernandez-Marine, M., Urzi, C., Groth, I., Schroeckh, V., Saarela, M., Mattila-Sandholm, T., Gallon, J.R., Graziottin, F., Bisconti, F., and Giuliani, R., 2003, Cyanobacteria attack rocks (CATS): Control and preventive strategies to avoid damage caused by cyanobacteria and associated microorganisms in Roman hypogean monuments, in Saiz-Jimenez, C., ed., Molecular Biology and Cultural Heritage: Lisse, Netherlands, Zwets \& Zeitlinger, p. $151-162$.

Asencio, A.D., and Aboal, M., 2001, Biodeterioration of wall paintings in caves of Murcia (SE Spain) by epilithic and chasmoendolithic microalgae: Algological Studies/Archiv für Hydrobiologie, Supplement Volumes No. 103, p. 131-142.

Bish, D.L., and Post, J.E., 1993, Quantitative mineralogical analysis using the Rietveld full-pattern fitting method: American Mineralogist, v. 78, p. 932-940.

Bischoff, H.W., and Bold, H.C., 1963, Some soil algae from Enchanted Rock and related algal species: Austin, University of Texas Publication no. 6318, Phycological Studies no. 4, 95 p.

Castenholz, W., 1988, Culturing methods for Cyanobacteria, in Parker, L., and Glazer, A.N., eds., Cyanobacteria: Elsevier, Methods in Enzymology, no. 167, p. 68-93. doi:10.1016/0076-6879(88)67006-6.

Chelius, M.K., Beresford, G., Horton, H., Quirk, M., Selby, G., Simpson, R.T., Horrocks, R., and Moore, J.C., 2009, Impacts of alterations of organic inputs on the bacterial community within the sediments of Wind Cave, South Dakota, USA: International Journal of Speleology, v. 38 , no. 1 , p. $1-10$.

Ciniglia, C., Cennamo, P., De Stefano, M., Pinto, G., Caputo, P., and Pollio, A., 2007, Pinnularia obscura Krasske (Bacillariophyceae, Bacillariophyta) from acidic environments: characterization and comparison with other acid-tolerant Pinnularia species: Fundamental and Applied Limnology: Archiv für Hydrobiologie, v. 170, p. 29-47. doi:10.1127/1863-9135/2007/ 0170-0029.

Couté, A., and Yéprémian, C., 2002, L'homme et les algues des cavernes, in M. F. Roquebert, M.F., ed., Les contaminants biologiques des biens culturels, Paris, Elsevier, Collection Patrimoine, p. 33-55.

Crispim, C.A., and Gaylarde, C.C., 2005, Cyanobacteria and biodeterioration of cultural heritage: a review. Microbial Ecology, v. 49, p. 1-9. doi:10.1007/s00248-003-1052-5.

Dayner, D.M., and Johansen, J.R., 1991, Observations on the algal flora of Seneca Caverns, Seneca County, Ohio: Ohio Journal of Science, v. 91, p. $118-121$.

de'Gennaro, M., Cappelletti, P., Langella, A., Perrotta, A., and Scarpati, C., 2000, Genesis of zeolites in the Neapolitan Yellow Tuff: geological, volcanological and mineralogical evidence: Contributions to Mineralogy and Petrolology, v. 139, p. 17-35. doi:10.1007/s004100050571.

Díez, B., Pedrós-Alió, C., and Massana, R., 2001, Study of genetic diversity of eukaryotic picoplankton in different oceanic regions by small-subunit rRNA gene cloning and sequencing: Applied and Environmental Microbiology, v. 67, p. 2932-2941. doi:10.1128/ AEM.67.7.2932-2941.2001.

Dobat, K., 1970, Considérations sur la végétation cryptogamique des grottes du Jura Souabe (sud-ouest de l'Allemagne): Annales de Spéléologie, v. 25 , no. 4 , p. $872-907$. 
Dodds, W.K., Gudder, D.A., and Mollenhauer, D., 1995, The ecology of Nostoc: Journal of Phycology, v. 31, p. 2-18. doi:10.1111/j.00223646.1995.00002.x.

Doyle, J.J., and Doyle, J.L., 1990, Isolation of plant DNA from fresh tissue: Focus, v. 12, p. 13-15.

Friedmann, I., 1956, Beiträge zu Morphologie und Formwechsel der atmophytischen Bangioidee Phragmonema sordidum: Zopf. Österreichische botanische Zeitschrift, v. 103, p. 613-633.

Gallon, J.R., Hashemm, M.A., and Chaplina, A.E., 1991, Nitrogen fixation by Oscillatoria spp. under autotrophic and photoheterotrophic conditions: Journal of General Microbiology, v. 137, p. 31-39. doi:10.1099/ 00221287-137-1-31.

Hoffmann, L., 1986, Cyanophycées aériennes et subaériennes du GrandDuché de Luxembourg: Bulletin du Jardin Botanique National de Belgique, v. 56, p. 77-127.

Hoffmann, L., 1989, Algae of terrestrial habitats: Botanical Review, v. 55, p. 77-105. doi:10.1007/BF02858529.

Huss, V.A.R., Frank, C., Hartmann, E.C., Hirmer, M., Kloboucek, A., Seidel, B.M., Wenzeler, P., and Kessler, E., 1999, Biochemical taxonomy and molecular phylogeny of the genus Chlorella sensu lato (Chlorophyta): Journal of Phycology, v. 35, p. 587-598. doi:10.1046/j.15298817.1999.3530587.x.

Insinga, D., Calvert, A., D’Argenio, B., Fedele, L., Lanphere, M., Morra, V., Perrotta, A., Sacchi, M., and Scarpati, C., 2004, ${ }^{40} \mathrm{Ar} /{ }^{39}$ Ar dating of the Neapolitan Yellow Tuff eruption (Campi Flegrei, southern Italy): volcanological and chronostratigraphic implications. European Geophysical Union 1st General Assembly, Nice, 2004 (abstract).

Lawton, L., Marsalek, B., Padisák, J., and Chorus, I., 1999, Determination of Cyanobacteria in the laboratory, in Chorus, I., and Bartram, J., eds., Toxic Cyanobacteria in Water: A Guide to Their Public Health Consequences, Monitoring and Management, London, E \& FN Spon Press, p. 347-368.

Le Clerc, J.C., Couté, A., and Dupuy, P., 1983, Le climat annuel de deux grottes et d'une église du Poitou, ou vivent des colonies pures d'algues sciaphiles: Cryptogamie Algologie, v. 4, p. 1-19.

Macedo, M.F., Miller, A.Z., Dionísio, A., and Saiz-Jimenez, C., 2009, Biodiversity of cyanobacteria and green algae on monuments in the Mediterranean Basin: an overview: Microbiology, v. 155, p. 3476-3490. doi:10.1099/mic.0.032508-0.

Martínez, A., and Asencio, A.D., 2010, Distribution of cyanobacteria at the Gelada Cave (Spain) by physical parameters: Journal of Cave and Karst Studies, v. 72, no. 1, p. 11-20. doi:10.4311/jcks20091sc0082.

Morra, V., Calcaterra, D., Cappelletti, P., Colella, A., Fedele, L., de' Gennaro, R., Langella, A., Mercurio, M., and de' Gennaro, M., 2010, Urban geology: relationships between geological setting and architectural heritage of the Neapolitan area, in Beltrando, M., Peccerillo, A., Mattei, M., Conticelli, S., and Doglioni, C., eds., The Geology of Italy: tectonics and life along plate margins, Journal of the Virtual Explorer, v. 36, paper 27. doi:10.3809/jvirtex.2010.00261.

Mulec, J., Kosi, G., and Vrhovšek, D., 2007, Algae promote growth of stalagmites and stalactites in karst caves (Škocjanske jame, Slovenia): Carbonates and Evaporites, v. 22, no. 1, p. 6-10. doi:10.1007/ BF03175841.

Mulec, J., Kosi, G., and Vrhovšek, D., 2008, Characterization of cave aerophytic algal communities and effects of irradiance levels on production of pigments: Journal of Cave and Karst Studies, v. 70, no. 1 , p. 3-12.

Orsi, G., De Vita, S., and di Vito, M., 1996, The restless, resurgent Campi Flegrei nested caldera (Italy): constraints on its evolution and configuration: Journal of Volcanology and Geothermal Research, v. 74, p. 179-214. doi:10.1016/S0377-0273(96)00063-7.

Ott, F.D., and Seckbach, J., 1994, New classification for the genus Cyanidium Geitler 1933, in Seckbach, J., ed., Evolutionary Pathways and Enigmatic Algae: Cyanidium caldarium (Rhodophyta) and Related Cells, New York, Springer, Developments in Hydrobiology, v. 91, p. $145-152$

Pagano, M., Redd, M., and Roddaz, J.-M., 1982. Campi Flegrei Marsilio Editore.

Pedersen, K., 2000, Exploration of deep intraterrestrial microbial life: current perspective: FEMS Microbiology Letters, v. 185, p. 9-16. doi:10.1111/j.1574-6968.2000.tb09033.x.

Pinto, G., Ciniglia, C., Cascone, C., and Pollio, A., 2007, Species composition of Cyanidiales assemblages in Pisciarelli (Campi Flegrei, Italy) and description of Galdieria phlegrea sp. nov., in Seckbach, J., ed., Algae and Cyanobacteria in Extreme Environments, Dortrecht, Netherlands, Springer, Cellular Origin, Life in Extreme Habitats, and Astrobiology, v. 11, p. 487-502. doi:10.1007/ 978-1-4020-6112-7_26.

Podani, J., 2001, SYN-TAX 2000 Computer Program for data analysis in Ecology and Systematics: User's Manual, Budapest, Scientia, 53 p.

Rajola, T., and N. Fiorillo in Paoli, P.A., 1978, Table 60 Naples, Biblioteca Nazionale Vittorio Emanuele III, Roma.

Roldán, M., and Hernández-Mariné, M., 2009, Exploring the secrets of the three-dimensional architecture of phototrophic biofilms in caves. International Journal of Speleology, v. 38, no. 1, p. 41-53.

Saiz-Jimenez, C., Garcia-Rowe, J., Garcia Del Cura, M.A., Ortega-Calvo, J.J., Roekens, E., and Van Grieken, R., 1990, Endolithic cyanobacteria in Maastricht limestone: Science of the Total Environment, v. 94, no. 3, p. 209-220. doi:10.1016/0048-9697(90)90171-P.

Sakamoto, T., and Bryant, D.A., 1999, Nitrate transport and not photoinhibition limits growth of the freshwater Cyanobacterium Synechococcus species PCC 6301 at low temperature: Plant Physiology, v. 119, p. 785-794. doi:10.1104/pp.119.2.785.

Saunders, G.W., and Hommersand, M.H., 2004, Assessing red algal supraordinal diversity and taxonomy in the context of contemporary systematic data: American Journal of Botany, v. 91, no. 10, p. 1494-1507. doi:10.3732/ajb.91.10.1494.

Scarpati, C., Cole, P., and Perrotta, A., 1993, The Neapolitan Yellow Tuff-A large volume multiphase eruption from Campi Flegrei, Southern Italy: Bulletin of Volcanology, v. 5 5, p. 343-356. doi:10.1007/BF00301145.

Scheerer, S., Ortega-Morales, O., and Gaylarde, C., 2009, Microbial deterioration in stone monuments-an updated overview, in Laskin, A., Gadd, G., and Sariaslani, S., eds., Advances in Applied Microbiology, Volume 66: San Diego, Academic Press, p. $97-130$.

Schwabe, G.H., 1936, Über einige Blaualgen aus dem mittleren und südlichen Chile: Verhandlungen des Deutschen Wissenschaftlichen Vereins zu Santiago de Chile, v. 3, p. 113-174.

Schwabe, G.H., 1944, Umraumfremde Quellen, Shanghai, M. Nössler, Mitteilungen der Deutschen Gesellschaft für Natur- und Völkerkunde Ostasiens supplement 21, $300 \mathrm{p}$.

Sieminska, J., 1962, The red alga Phragmonema sordidum in the Sibyl cave nearby Naples: Acta Hydrobiologie, v. 4, no. 2, p. 225-227.

Skuja, H., 1970, Alghe cavernicole nelle zone illuminate delle grotte di Castellana (Murge di Bari): Le Grotte d'Italia, Ser. 4, v. 2, p. 193-202.

Stal, L.J., 2000, Cyanobacterial mats and stromatolites, in Whitton, B., and Potts, M., eds., Ecology of the Cyanobacteria: Their Diversity in Space and Time, Dortrecht, Netherlands, Kluwer, p. 61-120. 